\title{
Malasseziosis Associated with Hypothyroidism- A Clinical Report in a Dog
}

\author{
GS Haritha, G Saritha* and K Nalini Kumari \\ Department of veterinary medicine, College of Veterinary Science, India
}

Submission: April 15, 2017; Published: April 28, 2017

*Corresponding author: G Saritha, Department of veterinary medicine, College of Veterinary Science, Tirupathi, India, Tel: 990827221 . Email: drsaritha.vet@gmail.com

Abstract

A five year male Labrador dog was presented with the history of lethargy, thin hair coat and alopecia with pruritis and was reported to have recurrent skin infection. The dog was previously treated with Ivermectin and antibacterial shampoos. Animal was dull, feed intake was reported to be normal and clinical parameters were normal. Detailed examination revealed bilateral alopecia, rat tail appearance and thickening with hyper pigmentation of skin. The impression smears from lesions were stained with methylene blue that revealed Malassezia organisms. Whole blood sample and serum were collected and subjected to haemato-biochemical estimations (thyroid function tests i.e., $\mathrm{T}_{3}$, $\mathrm{T}_{4}$ and TSH) which showed decreased production of $\mathrm{T}_{3}$ and elevated TSH secretion (Triiodothyronine $\left(\mathrm{T}_{3}\right) 32.1 \mathrm{ng} / \mathrm{dl}$, Thyroxine (T4) $0.5 \mathrm{mcg} /$ $\mathrm{dl}$ and TSH $8.7 \mathrm{ng} / \mathrm{ml}$ ) indicating hypothyroidism. Hematology was found to be in normal range.

ECG showed bradycardia. The dog was treated accordingly with thyroxine supplementation Levothyroxine sodium (Eltroxin ${ }^{\mathrm{a}}$ tab) $@ 0.02 \mathrm{mg} / \mathrm{kg}$ b.wt. twice daily and Ketaconazole @ $10 \mathrm{mg} / \mathrm{kg}$ b.wt orally and topical application of Ketochlor ${ }^{\mathrm{b}}$ shampoo. Significant improvement was noticed after two weeks and complete recovery was noticed after 25 days with healthy skin coat and increased activity. Hypothyroidism is one of the most commonly diagnosed endocrinopathies in dogs characterized by decreased levels of thyroid hormones and is having a major role in maintaining normal cutaneous functions. Hypothyroidism may lead to poor skin and hair coat, including hair loss or abnormal hair turnover, dull or brittle hair, altered pigmentation, oily or dry and thickened skin and thereby predispose to secondary bacterial and/or yeast dermatitis [1]. Diagnosis is based on an appropriate history, clinical signs, lab work, and response to therapy to diagnose this disease. A case of hypothyroidism in a dog with malasseziosis and its successful management is presented here.

\section{Case Report}

A five year male Labrador dog was presented with the history of lethargy, thin hair coat and alopecia with pruritis and was reported to have recurrent skin infection. The dog was previously treated with Ivermectin and antibacterial shampoos. Animal was dull, feed intake was reported to be normal and clinical parameters were normal. Detailed examination revealed bilateral alopecia, rat tail appearance and thickening with hyper pigmentation of skin. The impression smears from lesions were stained with methylene blue that revealed Malassezia organisms. Whole blood sample and serum were collected and subjected to haemato-biochemical estimations (thyroid function tests i.e., $\mathrm{T}_{3}, \mathrm{~T}_{4}$ and $\mathrm{TSH}$ ) which showed decreased production of $\mathrm{T} 3$ and elevated TSH secretion (Triiodothyronine $\left(\mathrm{T}_{3}\right) 32.1 \mathrm{ng} /$ $\mathrm{dl}$, Thyroxine $\left(\mathrm{T}_{4}\right) 0.5 \mathrm{mcg} / \mathrm{dl}$ and $\mathrm{TSH} 8.7 \mathrm{ng} / \mathrm{ml}$ ) indicating hypothyroidism. Hematology was found to be in normal range. ECG showed bradycardia. The dog was treated accordingly with thyroxine supplementation Levothyroxine sodium (Eltroxin ${ }^{\mathrm{a}}$ tab) @ 0.02mg/kg b.wt. twice daily and Ketaconazole @ 10mg/ $\mathrm{kg}$ b.wt orally and topical application of Ketochlor ${ }^{\mathrm{b}}$ shampoo.
Significant improvement was noticed after two weeks and complete recovery was noticed after 25 days with healthy skin coat and increased activity. Thyroid system plays a greater role in regulating several functions and influences the immune system and hence, when it is depressed or compromised, the whole body becomes more and more vulnerable to the insults which could be attributed to the secondary skin infections [2]. Dermatological changes are more commonly observed in $60-80 \%$ hypothyroid dogs. Hair coat changes and lethargy are always present with hypothyroidism and may have bradycardia. The clinical findings are similar to that of [3-5]. However, the clinical signs are quite variable and almost any organ or system may be involved. Though the diagnosis of hypothyroidism is based on abnormal thyroid function tests, clinically it is based on presence of classical clinical signs associated with skin and coat abnormalities and ultimately, adequate response to thyroid hormone replacement therapy [6]. While treating Malassezia dermatitis, it is important to identify the predisposing factors that can lead to yeast overgrowth, since Malassezia is usually a 
contributing factor, not the sole cause of clinical signs $[7,8]$. In the present case hypothyroidism was the predisposing factor

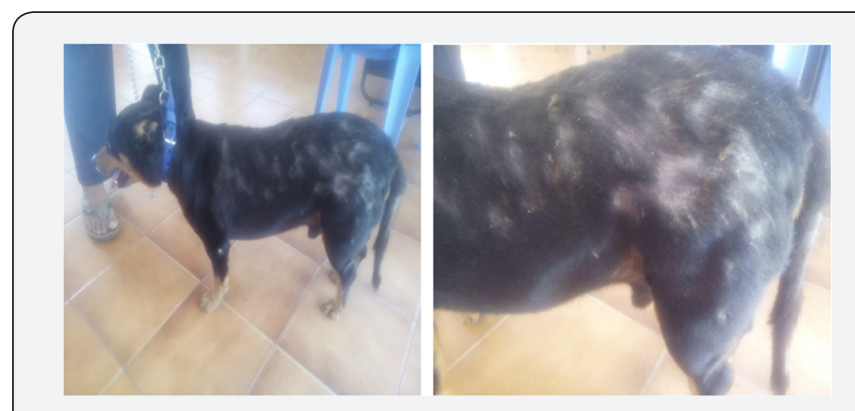

Figure1: Bilateral alopecia with rat tail appearance.

\section{References}

1. Ferguson EA, Bond R, Harvey RG (1993) Malassezia dermatitis: an emerging dermatosis. BrVet Dermatol Newsl 15: 40.

2. Satish Kumar K, Srikala D (2013) Hypothyroidism Associated Skin and Coat abnormalities in Dogs- A study of 49 patients. Intas Polivet 14(2): 427-431.

3. Muley VD, Digraskar SU, Sakhare MP, Rakh BJ (2010) Successful Management of Hypothyroidism in a Pushmi Dog - A Case Report. Intas Polivet 11(1): 98-99.

4. Satish Kumar K, Tirumala Rao DS, Sharma G (2007) A clinical study on hypothyroidism in dogs. Intas Polivet 8: 460-464. for Malassezia dermatitis and supplementation of thyroxine resulted in complete clinical recovery (Figure $1 \& 2$ ).

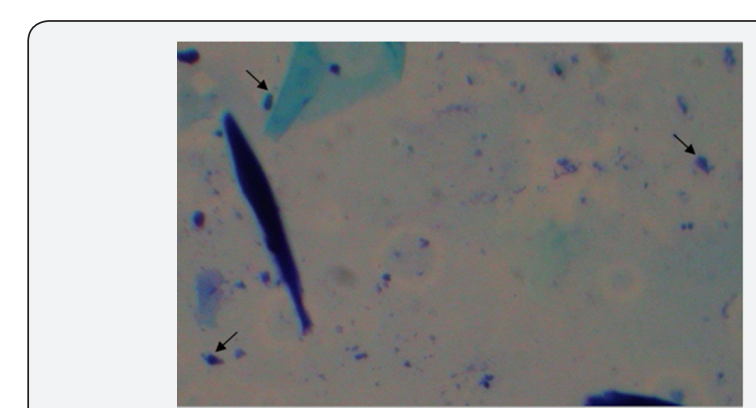

Figure2: Impression smear showing Malassezia organism.

5. Tresamol PV, Anumol J, Rathish RL (2013) Clinical Management of Malasseziosis associated with Hypothyroidism in a Dog. Intas Polivet 14 (2): 366-368.

6. Finora K, Greco D (2007) Compend Contin. Educ Vet 29: 19-31.

7. Mason KV, Evans AG (1991) Dermatitis associated with Malassezia pachy dermatis in 11 dogs. J Am Anim Hosp Assoc 27: 13-20.

8. Patterson AP, Frank LA (2002) How to diagnose and treat Malassezia dermatitis in dogs. Vet Med 97: 612-622.

\section{Your next submission with Juniper Publishers} will reach you the below assets

- Quality Editorial service

- Swift Peer Review

- Reprints availability

- E-prints Service

- Manuscript Podcast for convenient understanding

- Global attainment for your research

- Manuscript accessibility in different formats

( Pdf, E-pub, Full Text, Audio)

- Unceasing customer service

Track the below URL for one-step submission https://juniperpublishers.com/online-submission.php 